\title{
Rapid relative increase of crustose coralline algae following herbivore exclusion in a reef of El Salvador
}

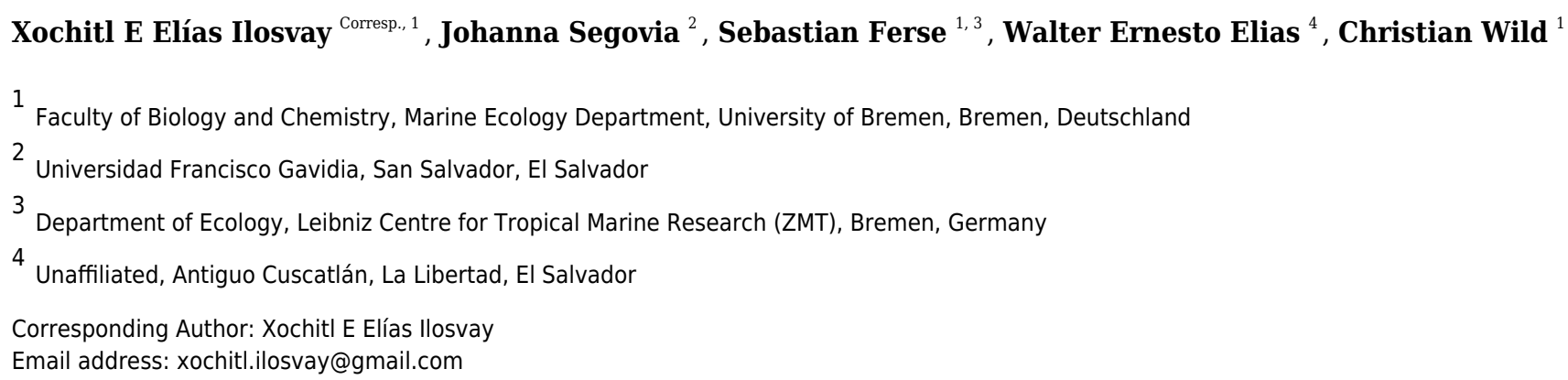

The Eastern Tropical Pacific (ETP) is one of the most isolated and least studied regions in the world. This particularly applies to the coast of El Salvador, where the only reef between Guatemala and Nicaragua, called Los Cóbanos reef, is located. There is very little published information about the reef's biodiversity, and to our knowledge, no research on its ecology and responses to anthropogenic impacts, such as overfishing, has been conducted. The present study, therefore, described the benthic community of Los Cóbanos reef, El Salvador, using the Line-Point-Intercept-Transect method and investigated changes in the benthic community following the exclusion of piscine macroherbivores over a period of seven weeks. Results showed high benthic algae cover (up to $98 \%$ ), dominated by turf and green algae, and low coral cover (0 - $4 \%$ ). Porites lobata was the only hermatypic coral species found during the surveys. Surprisingly, crustose coralline algae (CCA) showed a remarkable total cover increase by $58 \%$, while turf algae cover decreased by $82 \%$, in experimental plots after seven weeks of piscine macroherbivore exclusion. These findings apparently contradict the results of most previous similar studies. While it was not possible to ascertain the exact mechanisms leading to these drastic community changes, the most likely explanation is grazing on turf by small grazing macroherbivores that had access to the cages during the experiment and clearing of CCA initially covered by epiphytes and sediments. A higher CCA cover would promote the succesful settlement by corals and prevent further erosion of the reef framework. Therefore it is crucial to better understand algal dynamics, herbivory, and implications of overfishing at Los Cóbanos to avoid further reef deterioration. This could be achieved through video surveys of the fish community, night-time observations of the macroinvertebrate community, exclusion experiments that also keep out herbivorous macroinvertebrates, and/or experimental assessments of turf algae/CCA interactions. 


\section{Rapid relative increase of crustose coralline algae} 2 following herbivore exclusion in a reef of El Salvador

3

Xochitl E. Elías Ilosvay ${ }^{*}$, Johanna Segovia ${ }^{2}$, Sebastian C. A. Ferse ${ }^{1,3}$, Walter Elías ${ }^{4}$, Christian Wild $^{1}$

${ }^{1}$ Faculty of Biology and Chemistry, Marine Ecology Department, University of Bremen, Bremen, Germany

2 Universidad Francisco Gavidia, San Salvador, El Salvador

${ }^{3}$ Department of Ecology, Leibniz Centre for Tropical Marine Research (ZMT), Bremen, Germany

${ }^{4}$ Unaffiliated, Antiguo Cuscatlán, La Libertad, El Salvador

Corresponding Author:

Xochitl Édua Elías Ilosvay

Email address: xochitl.ilosvay@gmail.com

\section{Abstract}

The Eastern Tropical Pacific (ETP) is one of the most isolated and least studied regions in the world. This particularly applies to the coast of El Salvador, where the only reef between Guatemala and Nicaragua, called Los Cóbanos reef, is located. There is very little published information about the reef's biodiversity, and to our knowledge, no research on its ecology and responses to anthropogenic impacts, such as overfishing, has been conducted. The present study, therefore, described the benthic community of Los Cóbanos reef, El Salvador, using the LinePoint-Intercept-Transect method and investigated changes in the benthic community following the exclusion of piscine macroherbivores over a period of seven weeks. Results showed high benthic algae cover (up to $98 \%$ ), dominated by turf and green algae, and low coral cover ( 0 - 4 \%). Porites lobata was the only hermatypic coral species found during the surveys. Surprisingly, crustose coralline algae (CCA) showed a remarkable total cover increase by $58 \%$, while turf algae cover decreased by $82 \%$, in experimental plots after seven weeks of piscine macroherbivore exclusion. These findings apparently contradict the results of most previous similar studies. While it was not possible to ascertain the exact mechanisms leading to these drastic community changes, the most likely explanation is grazing on turf by small grazing 


\section{Introduction}

45

46

47

48

49

50

51

52

53

54

55

56

57

58

59

60

61

62

63

64

65

macroherbivores that had access to the cages during the experiment and clearing of CCA initially covered by epiphytes and sediments. A higher CCA cover would promote the succesful settlement by corals and prevent further erosion of the reef framework. Therefore it is crucial to better understand algal dynamics, herbivory, and implications of overfishing at Los Cóbanos to avoid further reef deterioration. This could be achieved through video surveys of the fish community, night-time observations of the macroinvertebrate community, exclusion experiments that also keep out herbivorous macroinvertebrates, and/or experimental assessments of turf algae/CCA interactions.

Many tropical reefs around the world are undergoing changes in benthic community composition (away from dominance by stony corals) as a result of the combined effect of anthropogenic disturbances (Hoegh-Guldberg et al., 2018; Hughes et al., 2007; Pandolfi et al., 2005). Studies show that by removing herbivores that consume macroalgae, overfishing may favor competitive fleshy algae and turf over corals and other reef-building organisms (Burkepile and Hay, 2006; Hughes et al., 2007; Smith et al., 2010). Reef herbivores directly affect the composition of reef benthic communities by freeing benthic space from macroalgae and allowing, for example, coral larval settlement (Lewis, 1986; Steneck,1995) and crustose coralline algae growth (CCA) (Mumby, 2009). The latter plays a crucial role in coral reef ecosystems by facilitating the settlement of coral larvae via chemical cues (Heyward and Negri, 1999; Ritson-Williams et al., 2010), solidifying the reef framework (Adey, 1998; Weiss and Martindale, 2017), and preventing bioerosion (Weiss and Martindale, 2017).

Several studies address the role that herbivorous fish and invertebrates play in the coral reefs of the Caribbean Sea and the Indo-Pacific (e.g. Foster, 1987; Green and Bellwood, 2009; Hughes et al., 2007; Lewis, 1986). The Caribbean Sea, for example, suffered a drastic decrease in coral cover after mass mortality of the sea urchin, Diadema antillarum, preceded by overfishing of herbivorous fishes on many Caribbean reefs (Jackson et al., 2014), while the Indo-Pacific is characterized by a large number of diverse herbivorous fishes, showing higher functional diversity among herbivorous fish than the Caribbean (Roff and Mumby, 2012). 
66

67 On the contrary, little research has been conducted on coral reefs of the Eastern Tropical Pacific

68 (ETP), which is one of the most isolated ocean regions in the world (Cortés, 2017; Glynn and 69 Ault, 2000). The reefs in the region are exposed to extreme environmental conditions, such as 70 high $\mathrm{CO}_{2}$ concentrations, low aragonite saturation, high levels of nutrients, high tidal amplitudes, 71 and extreme fluctuations in seawater temperature caused by the El Niño-Southern Oscillation 72 (Bennett, 1966; Cortés, 1997; Guzmán and Cortés, 1993; Kessler, 2006). Moreover, there is little 73 research on how herbivores structure benthic communities in the ETP. Only a few studies have 74 investigated the role of consumers through exclusion experiments in the region (e.g. Menge et 75 al., 1986; Vinueza et al. 2006; Vinueza et al. 2014; Roth et al., 2015).

77 Los Cóbanos reef, located in El Salvador, is the only known reef in the country with hermatypic 78 coral species. Los Cóbanos lies within the so-called "Pacific Central American Faunal Gap 79 (PCAFG)", which is the coastal stretch between Guatemala and northwestern Nicaragua (Cortés 80 et al., 2017). Los Cóbanos reef, together with the recently discovered reef at the coast of 81 Nicaragua, are the only two sites within the PCAFG that have been found to host significant 82 coral communities (Alvarado et al., 2010; Reyes-Bonilla and Barraza, 2003). 83

84 There is little information about Los Cóbanos reef. Reyes-Bonilla and Barraza (2003) reported 85 eight reef -building coral species belonging to the genera Porites, Pocillopora, and Pavona. 86 Unpublished management reports and surveys document that the reef is dominated by algae $(\sim 77$ $87 \%$ ) (Segovia-Prado and Navarrete-Calero, 2007), with 81 algae species reported (Arrivillaga et 88 al., 2010), and that hard coral cover is extremely low ( 4 \%) (Segovia-Prado, 2016). According 89 to Reyes-Bonilla and Barraza (2003), the fish abundance on the reef is low, but generally, 90 information about the fish community at Los Cóbanos is scarce. Fish play a crucial role in coral 91 reef systems by, for example, controlling macroalgae which compete with corals for space 92 (Bellwood et al., 2004; Mumby, 2015). Overfishing in coral reefs can increase overgrowth of 93 algae and/or other benthic organisms and lead to phase shifts from coral dominance to degraded 94 ecosystems (Bellwood et al., 2004; Loh et al., 2015; Pandolfi et al., 2005). Currently, the 95 literature states that around 137,000 kg of fish are being caught at Los Cóbanos (Arrivillaga et 96 al., 2010). Although several studies (e.g. Molina and Vásquez-Jandres, 2006; Segovia-Prado and 
97 Navarrete-Calero 2007) state that Los Cóbanos reef is overfished, to our knowledge, no research

98 has been conducted investigating how the piscine community affects benthic community 99 composition at Los Cóbanos reef. This study aimed to address those knowledge gaps by, firstly, 100 describing the current benthic community state of Los Cóbanos reef, and secondly, assessing the 101 effect of piscine macroherbivore exclusion on the benthic community using an in-situ exclusion 102 experiment, simulating overfishing. We hypothesized that the reef would exhibit high algae and 103 low coral cover (H1), and that by excluding piscine macroherbivores, macroalgae would 104 overgrow P. lobata colonies as suggested by previous studies (Hughes et al., 2007; Roth et al., 105 2015; Thacker et al., 2001) (H2).

106

107 Materials \& Methods

108

109

110

\section{Study site}

111

The study was carried out on Los Cóbanos reef (1331'25.6"N 8948'24.6"W), El Salvador, from March to May 2018. The reef lies within the nature reserve "Complejo Los Cóbanos", $11 \mathrm{~km}$ east of the city Acajutla (Fig. 1). The Ministry of Environment and Natural Resources of El Salvador (MARN, initials in Spanish) approved the fieldwork for this study inside the nature reserve. Los Cóbanos reef consists of a heterogeneous basalt shore with a tidal variation of $\sim 3 \mathrm{~m}$ (Segovia-Prado, 2016). Colonies of the hermatypic coral species Porites lobata grow inter- and subtidally, covering only $2-7 \%$ of the benthos. The region is characterized by two seasons: a dry (December to May) and a rainy (June to November) season. The benthic community at Los Cóbanos is exposed to sedimentation impacts during the raining season, when river runoff brings

\section{Benthic community survey}

122 The benthic community was evaluated using the Line-Point-Intercept-Transect method via 123 snorkelling, as described by English et al. (1997). In April 2018, seven $50 \mathrm{~m}$ long transects were 124 placed parallel to the coastline at 2-3 $\mathrm{m}$ water depth, with at least $25 \mathrm{~m}$ between individual transects. During low tide, for a total of 100 points per transect (one every $0.5 \mathrm{~m}$ ), the benthic organism underneath each point was identified in situ to genus level, except for turf and crustose coralline algae (CCA) that could not be identified to this level and were classified generically. If 
128 no organism was found on that point, non-living structures were categorized as: 'sand', 'rock' or 129 'Pocillopora sp. skeleton'. The relative benthic cover of each category was calculated using the 130 resulting 100 points per transect.

131

\section{Experimental cage set-up}

133 The experimental design followed the Before-After Control-Impact/Treatment (BACI) design

134 (Stewart-Oaten et al., 1986). Four $70 \times 70 \times 50 \mathrm{~cm}^{3}$ cages constructed from $2.5 \times 2.5 \mathrm{~cm}^{2}$

135 galvanized wire mesh (as used by Smith et al., 2001) were deployed on the reef with at least $2 \mathrm{~m}$ 136 distance from each other. Each cage enclosed one Porites lobata colony of a diameter of $8-12$

$137 \mathrm{~cm}$ and surrounding algae. Even though $P$. lobata only covered up to $4 \%$ of the benthos, it was

138 targeted in the experiment to assess how simulated overfishing affects coral-algae interactions.

139 Four more plots with a similar benthic community composition to the enclosed ones were

140 selected as controls $\left(70 \times 70 \mathrm{~cm}^{2}\right)$. The experiment ran for seven weeks, from April to May 2018.

141 Each week the cages were cleaned using a plastic washing brush to avoid algae growth. The

142 plots were inspected for small fish, snails, crustaceans and echinoderms every week during the

143 cleaning. None were observed in the enclosed plots. Also, the control plots were carefully

144 inspected weekly, but no macroinvertebrates were observed at any time. The cover of the

145 different algae functional groups in the enclosed and control plots was estimated in situ using

146 quadrats that indicated the cage limits $\left(70 \times 70 \mathrm{~cm}^{2}\right)$ to the nearest $1 \%$ at the beginning and the

147 end of the experiment. The same categories used during the benthic surveys were identified in

148 the exclusion experiment. Only the uppermost benthic community layers were analyzed. The

149 cover of $P$. lobata was estimated by comparing the projected area of the colony (calculated by

150 measuring the length and width of the colony at the beginning and end of the experiment) to the

151 total selected cage and control area $\left(0.49 \mathrm{~m}^{2}\right)$. All surveys were conducted by the first author.

152

153 Due to logistical constraints, it was not possible to include semi-closed cages to assess potential

154 physical effects of the cages in this experiment. CCA often perform better under lower light

155 availability than other algae (Van den Hoek et al., 1978, Vásquez-Elizono and Enríquez 2017),

156 while algal turfs increase their net primary productivity with increased water flow (Carpenter et

157 al., 1991; Carpenter and Williams, 2007). The cage structure could have reduced light

158 availability and water flow within the enclosed plots, benefiting CCA. In order to quantify the 
159 potential effects of the cages on water flow and light attenuation, gypsum cards and HOBO light 160 sensors were placed inside and outside cages with the same design as those used in the 161 experiments, at the experimental sites for $24 \mathrm{~h}$ in April 2019. The gypsum cards were weighed

162 before and after $24 \mathrm{~h}$ exposure to obtain an aggregate measure of water flow over that period.

163 The HOBO light sensors measured light intensity within and outside the cages in lum/ $\mathrm{ft}^{-2}$ every 16430 seconds.

165

\section{Data analysis}

167 The mean relative cover of each functional group identified in the benthic community survey 168 was calculated using the relative cover of all transects. To compare the community composition 169 of the control and enclosed plots at the beginning and end of the experiment, Bray - Curtis 170 Dissimilarity was calculated on untransformed data, and a PERMANOVA test was conducted 171 using PRIMER 7. For the pair-wise comparisons, Monte Carlo P-values were obtained using 172 PRIMER 7 due to the small number of permutations resulting from the PERMANOVA test, as 173 suggested by Anderson et al. (2008). All additional tests were conducted in the statistics program 174 R version 3.5.1 (R Core Team, 2018). Differences in coral, CCA, and turf benthic cover were 175 tested with repeated measures ANOVA (rmANOVA from the ez package, Lawrence, 2016). In 176 order to test the weight difference of the gypsum cards after the $24 \mathrm{~h}$ exposure, a t-test (from the 177 stats package) was conducted. To test for potential differences in the measured light intensities, a 178 Wilcoxon Rank Sum test (stats package) was used, as normality and sphericity assumptions were 179 not met. An Anderson-Darling-Test (ADGofTest package) was used to test for data normality 180 and Levene's-test (from the car package) was used to test sphericity assumptions. The jitter 181 function (from ggplot2 package, Wickham et al., 2019) was used to add random variation to the 182 non-metric multidimensional scaling (nMDS) plot and reveal the points with the same 183 community assemblage that were overlapping.

\section{Results}

187 Benthic community survey

188 The benthic community composition of Los Cóbanos reef was dominated by algae. Different 189 types of algae comprised $72-98 \%$ of the benthic community. Turf algae were the most 
190 dominant algae group, with a mean benthic cover of $26.6 \pm 8.8$ (SD) $\%$, followed by green algae 191 with $22.8 \pm 21.2$ (SD) \% (Table 1). Only one hermatypic coral species was found alive (Porites 192 lobata), which had a benthic cover of $2.0 \pm 2.8$ (SD) \%. Calcium carbonate skeletons of the 193 branching coral genus Pocillopora were widely observed. Mobile benthic macroinvertebrates 194 were not observed within the transects; however, the nudibranchs Elysia diomedea and 195 Glossodoris sedan and the echinoderms Ophiocoma aethiops, Echinometra vanbrunti, and 196 Holothuria (Halodeima) kefersteinii were observed on the reef during the benthic surveys 197 (Supplementary Materials, Table S1).

198

199

\section{Fish herbivore exclusion}

200 No significant effect of cage structures was observed on either light intensity (Wilcoxon Rank Sum test, $\mathrm{p}=0.520$ ) or water flow ( $\mathrm{t}$-test, $\mathrm{t}(2.08)=-1.21, \mathrm{p}=0.343)$, indicating that the physical 202 structure of the cages did not affect light or water flow.

203

204

There was a significant interaction effect of treatment and time on the benthic community 205 composition $($ PERMANOVA, $\mathrm{P}($ perms $)=0.001$, perms $=996)$. The benthic community

206 composition in the enclosed and control plots only differed significantly at the end of the experiment $($ PERMANOVA, $\mathrm{P}($ perms $)=0.027$, perms $=35, \mathrm{P}(\mathrm{MC})=0.007)$ (Fig. 2,

208

209

210

211

212

213

214

215

216

217

218

219

19 Supplementary Materials, Tables S2 and S3). The benthic community composition in the enclosed $($ PERMANOVA, $\mathrm{P}($ perms $)=0.030$, perms $=35, \mathrm{P}(\mathrm{MC})=0.001)$ and control $($ PERMANOVA, $\mathrm{P}($ perms $)=0.028$, perms $=35, \mathrm{P}(\mathrm{MC})=0.003)$ plots changed significantly between the beginning and the end of the experiment. Crustose coralline algae cover increased by a total $57.5 \%$ (from 0 to $57.5 \pm 9.6$ (SD) \%) in the enclosed plots and $21.5 \%$ (from $1 \pm 1.4$ (SD) \% to $22.5 \pm 8.66$ (SD) \%) in the control plots, while the turf algae benthic cover decreased by $81 \%$ (from $83.8 \pm 4.7$ (SD) \% to $2 \pm 2.3$ (SD) \%) in the enclosed plots and $63 \%$ (from 79.75 \pm 4.3 (SD) $\%$ to $16.5 \pm 7$ (SD) \%) in the controls (Fig. 3). There was a significant interactive effect of treatment and time on both the CCA (rmANOVA, $\mathrm{F}_{(1,6)}=27.47, \mathrm{p}=0.003$ ) and turf algae benthic cover (rmANOVA, $\left.\mathrm{F}_{(1,6)}=14.69, \mathrm{p}=0.009\right)$.

\section{Discussion}




\section{Benthic community survey}

222 This study aimed to describe the current state of the benthic community of Los Cóbanos reef, El

223 Salvador, and to investigate the effect of piscine macroherbivore exclusion on benthic

224 community composition. As expected (H1), the survey results show that the reef was dominated

225 by algae (mostly turf and green algae) and that the coral cover was extremely low. Compared to

226 the coral diversity described for the same reef by Reyes-Bonilla and Barraza (2003), the number

227 of living hermatypic coral species present decreased from five to one in less than two decades.

228 Past unpublished surveys conducted at Los Cóbanos yielded similar results; however, the

229 reported algae cover was slightly lower two years prior the present study $(\sim 72 \%)$ (Herrera

230 2017). Yearly surveys conducted by J. Segovia using permanent transects reported a coral cover

231 decrease from $6 \%$ to $2 \%$ between 2014 and 2016. Segovia et al. (2019) and Segovia (2020),

232 using haphazardly deployed transects, documented a P. lobata cover of $2 \%$ in 2019 and 2020, in

233 line with the value observed in this study for 2018. In contrast to the present study, the benthic

234 community in Los Cóbanos has been mainly surveyed using 30-meter long transects at three

235 different distances from the shore and a $1 \mathrm{~m}^{2}$ quadrat (Segovia-Prado, 2016; Segovia et al., 2019;

236 Segovia, 2020). Regardless of the difference in the monitoring methodology, the results of the

237 different surveys yield very similar results, indicating a clear decrease of hard coral cover over

238 time up to 2016, mainly attributed to El Niño events in 2014 and 2016 (Segovia et al., 2019).

239 Moreover, according to personal communication with fishers from the local community, 20 - 30

240 years ago, Pocillopora sp. cover in the shallow parts of the reef was high. According to the

241 fishers, the only way to access the reef was during high tide with the help of boats, suggesting a

242 much higher coral cover and a higher hard coral diversity than the present one. A vast number of

243 calcium carbonate skeletons, some of them still attached to the substrate, belonging to the coral

244 genus Pocillopora were observed during the surveys, indicating this genus comprised a

245 significant component of the shallow benthic community in the recent past.

246

247 Studies of other reefs in the ETP showed a higher hard coral species richness (2-3 coral species)

248 than at Los Cóbanos (Guzmán and Cortés, 1993; Reyes-Bonilla et al., 2010; Stuhldreier et al.

249 2015). Turf algae also seem to dominate other ETP reefs (Cortés et al., 2017; Stuhldreier et al.,

250 2015). Yet, these reefs display a lower algae diversity, with only two or three macroalgae genera 
251 dominating the reef benthos (Stuhldreier et al., 2015), compared to nine different genera found at 252 Los Cóbanos.

253

254 Cortés et al. (2017) state that the increasing temperature and length of El Niño events,

255 sedimentation, and local human activities have caused reef degradation in the region. The coral 256 cover of Los Cóbanos reef decreased drastically in the last decades. Two oil spills in El Salvador 257 in 1993 together with extreme El Niño events may have caused the disappearance of most of the 258 coral community of Los Cóbanos (Cortés et al., 2017; Molina, 1996; Alvarado, 2012; Segovia et 259 al., 2019). Currently, the reef is exposed to high nutrient input from the local human population, 260 intense fishing, and sedimentation (Herrera, 2017, unpublished; Reyes-Bonilla and Barraza, 261 2003). The hard coral population is limited to a small area at $0-15 \mathrm{~m}$ water depth extending for 262 about 7,000 $\mathrm{m}$ along the coastline between Punta Remedios and Acajutla (Fig. 1) (pers. obs. J 263 Segovia). The results of this study, together with the aforementioned literature, suggest that Los 264 Cóbanos reef may have undergone a shift from a reef with high coral cover towards a rather 265 algae-dominated reef, as described by Pandolfi et al. (2005) for other regions of the world, at 266 least in the first 600 meters from the coast. Bellwood et al. (2004) defined coral reefs as "three267 dimensional shallow-water structures dominated by scleractinian corals". The low coral cover 268 and high algae cover and diversity underline that Los Cóbanos is no longer a coral reef but rather 269 an algal-dominated reef. Concordantly, recent literature refers to Los Cóbanos reef as rather a 270 rocky reef featuring hard coral and algal communities (Herrera, 2017, unpublished; Segovia, 271 2017). There is, however, no historical monitoring data that verifies the assumption that Los 272 Cóbanos reef was indeed a coral reef in the past. Core drilling and examination of the underlying 273 matrix might be able to resolve this question.

274

\section{Herbivore exclusion}

276

277 Unexpectedly, CCA cover increased in both enclosed (by a total of ca. $58 \%$ ) and control areas 278 (ca. $21 \%$ ), while turf algae decreased in both treatments (enclosed ca. $82 \%$, control ca. $63 \%$ ) at 279 a remarkable speed. As CCA are among the slowest-growing marine algae, it is unlikely that this 280 result reflects actual growth of CCA. Rather, at least some CCA may have been covered by turf281 forming fouling epiphytes, the removal of which would have led to an apparent short-term 
282 increase in CCA. CCA are often considered as subordinate in their capacity to compete for space 283 and are often overgrown or shaded by turf or macroalgae (Dethier et al., 1994; Littler and Littler, 284 1980). In some cases, this overgrowth even provides protection to CCA from harmful 285 environmental conditions (Figueiredo et al., 2000). However, our results cannot confirm this, as 286 only the uppermost layer of the benthic community was analyzed at the beginning and end of the 287 experiment. No observations were made on whether CCA could indeed be found living under the

288 289 290

291

292

293

294

295

296

297

298

299

300

301

302

303

304

305

306

307

308

309

310

311

312 turf algae. The exclusion of large piscine herbivores through caging had a significant effect on the benthic community composition. Surprisingly, there was a significantly higher apparent increase in CCA cover in the enclosed areas, whereas turf algae decreased more in the absence of piscine macroherbivores (Fig. 3). This is remarkable, as most literature indicates that herbivore exclusion causes an increase of macro- and turf algae (e.g. Hughes et al., 2007; Roth et al., 2015; Thacker et al., 2001; Zaneveld et al., 2016). No effect of the cage structures on the current regime or light availability was detected through the $24 \mathrm{~h}$ measurements, meaning that the stronger observed benthic community changes in the enclosed plots were presumably caused by biotic factors. Nevertheless, the extent to which these results can be transferred to the sevenweek experimental period is limited. High frequency data loggers were used to monitor light changes over a $24 \mathrm{~h}$ period on a day that was representative for the study period during the dry season. However, these measurements may not be representative for the study transition period from the dry to rainy season. Our study thus is not able to directly determine the biotic and abiotic processes behind the phenomenon observed at Los Cóbanos. Therefore, potential explanations for these counterintuitive results are discussed in the following paragraphs.

\section{Low light and high nutrient availability}

The experiment at Los Cóbanos reef was conducted from April to the end of May, the transition months from the dry to the rainy season. During these months, there were several rainfalls which drastically decreased the underwater visibility through sediment input, and possibly increased the nutrient concentration via river runoff. Low light availability has been reported to negatively affect turf algae growth (Russel 2007). Fricke et al. (2011) attributed the decrease of turf biomass to the depth-related decrease in light quantity. The change in the light conditions could have reduced the turf algae uncovering the CCA beneath it. However, little is known about the response of turf algal communities to changes in abiotic factors and further experiments would 
313 be needed to test this (Fricke et al. 2014). On the other side, CCA tolerate lower light availability 314 (Van den Hoek et al., 1978, Vásquez-Elizono and Enríquez 2017) and have been reported to be 315 nutrient-limited (Smith et al. 2001). The sudden high nutrient input may have allowed CCA to 316 survive the sudden change in light availability, contrary to the turf algae. Similar seasonal 317 observations were made by Menge et al. (1986) at a rocky shore in Panama where the cover of 318 coralline crust increased during the rainy season and decreased during the dry season. The 319 change in abiotic conditions due to seasonal changes at the study site may have driven the unexpected turf algae decrease and apparent CCA increase in the enclosed and control plots.

321

322

\section{Exclusion of piscine macroherbivores}

323 In this study, the apparent CCA cover increase within the cages relative to the controls could 324 have been caused by the exclusion of fauna that either feeds on turf algae or benefits its growth 325 through, for example, farming behavior. Underwater visual fish censuses were conducted at Los 326 Cóbanos during the study period; however, the results showed great variability. For this reason,

327

328

329

330

331

332

333

334

335

336

337

338

339

340

341

342

343 the results were not used in this study. Nonetheless, the highly territorial turf algae farming fish species Stegastes acapulcoensis (Dominici-Arosemena and Wolff, 2008; Robertson and Allen, 2015) was found in high numbers in the census transects. As the presence of damselfishes can favor the growth of turf algae over CCA in algae dominated reefs (Doropoulos et al., 2013), the exclusion of $S$. acapulcoensis may have been to the detriment of turf algae, contributing to their strong decrease. A further explanation could be the exclusion of detritivores, such as surgeonfish that remove sediments and detritus from turf algae (Purcell and Bellwood, 1993; Tebbett et al., 2017). This could have benefited CCA in a similar way to observations by Kendrick (1991), who carried out a study in the Galapagos archipelago and found that, after 51 days of experimentation, algal turf cover and recruitment decreased in treatments with a high rate of sedimentation favoring crustose coralline algae. This way, the exclusion of a key non-identified detritivore could have magnified the effect of sediment deposition on turf algae, without detrimental effects on CCA.

\section{Grazing activity of macroinvertebrates}

A more probable explanation for the observed rapid decrease of turf algae and concomitant increase in CCA within the enclosed areas appears to be the grazing activity of smaller

Peer) reviewing PDF | (2020:07:50908:3:0:NEW 3 Dec 2020) 
344 macroinvertebrates such as snails, sea urchins, or crabs. Following exclusion of larger fishes,

345 invertebrate micrograzers have been shown to lead to shifts in community composition and

346 reduced algal biomass (Brawley and Adey, 1981; Zeller, 1988). The deployed cages could have

347 provided an accessible predator-free habitat for small benthic grazers. Rather than leading to a

348 reduction in grazing, exclusion of fishes may thus have increased consumption of turf algae and

349 other fouling epiphytes, uncovering previously hidden CCA. Although no macroinvertebrates

350 were observed in or around the cages during the study, many macroinvertebrates are active at

351 night, when the cages would have offered refuge from mesopredators. The sea urchin

352 Echinometra vanbrunti, for example, was observed hidden between rocks during the benthic

353 surveys in the reef. Furthermore, the weekly examinations were made in short periods during

354 extreme low tides, when small invertebrates sought shelter from rising water temperatures and

355 increased wave activity in crevices, tide pools or deeper parts of the reef. Additionally, no

356 nocturnal observations were made that could verify the nocturnal grazing activity of sea urchins

357 (Nelson and Vance 1979; Mills et al., 2000). In exclusion experiments conducted on rocky

358 shores in Galápagos and the Bay of Panama, when small grazers such as gastropods, crabs, and

359 small fishes were not excluded, the CCA cover increased after 16 and 8 weeks, respectively

360 (Menge et al., 1986; Vinueza et al., 2006). The CCA cover in the exclusion experiment on the

361 Panamanian rocky shores was highest when only large fish were excluded from the areas (Menge

362 et al., 1986), similar to the design in the present study.

363

364 This study's results suggest that biotic factors do affect the benthic community composition at

365 Los Cóbanos. Even though CCA can suppress macroalgae in other ETP reefs (Smith et al., 2001;

366 Vermeij et al., 2011), this experiment does not provide evidence that CCA could effectively

367 outcompete turf algae, and that the observed increases were the result of actual CCA growth. If

368 that were the case, growth of CCA in this study would have, by far, exceeded the CCA growth

369 rates reported everywhere else in the tropics (e.g. Adey and Vassar, 1975; Villas Boas et al.,

370 2005; Tamega and Figueiredo, 2019). A more likely explanation for the apparent rapid increase

371 of CCA cover is the loss of turf algae and other fouling epiphytes growing on CCA as a result of

372 the grazing activity of small macroinvertebrates, thereby uncovering the CCA living underneath.

373 CCA can survive overgrowth by filamentous turfs over long periods of time (Kendrick 1991;

374 Airoldi, 2000). Lapointe (1997) proposed that high nutrient availability and high grazing activity 
375 lead to CCA benthic dominance. Against expectations, simulated overfishing benefited 376 calcifying algae (H2). Our results, however, highlight the potential importance of

377 macroinvertebrates as grazers whose population seems to be controlled by piscine mesopredators 378 at Los Cóbanos. Macroinvertebrates composed less than $1 \%$ of the benthic community in the 379 reef. The underwater visual fish census also revealed a large number of piscine mesopredators at 380 Los Cóbanos, such as the wrasses Halichoeres dispilus, H. notospilus, and Thalassoma 381 lucasanums that feed on benthic invertebrates such as small crabs, snails and sea urchins 382 (Gomon 1995). The high number of mesopredators is possibly the result of overfishing of top 383 predators such as sharks, barracudas, and large groupers, allowing mesopredators to proliferate 384 (Hixon 2015; Prugh et al., 2009). Future fishing management strategies at Los Cóbanos could 385 focus on controlling the population of mesopredators by, for example, reducing the fishing 386 intensity on top predators.

387

\section{Conclusions}

389 It is most likely that the combination of grazing macroinvertebrates, increased nutrient 390 concentration and turbidity as a result of seasonal river run-off, and potential effects of the cages, 391 tipped the balance from turf algae to CCA. This phenomenon has been observed in other ETP 392 reefs (Menge et al., 1986; Vinueza et al., 2006). However, due to the methodological limitations 393 of the experiment, this study could not determine the drivers of the unexpected apparent increase 394 in CCA cover observed at Los Cóbanos. Therefore, further experiments assessing the interaction 395 between CCA and turf algae under different abiotic conditions at Los Cóbanos should be 396 conducted. In addition, targeted studies of the fish and macroinvertebrate communities, their role 397 in structuring the benthic community, and their trophodynamics are needed for a better 398 understanding of the ecology of Los Cóbanos reef. Understanding the processes affecting the 399 persistence of an important benthic component such as CCA is crucial first to understand the 400 failed recovery of stony corals as in Los Cóbanos reef and secondly to take accurate management 401 measures to avoid further deterioration.

402

\section{Acknowledgements}


405 We thank to Ana María Velásquez and the rest of the park rangers for their support during this 406 study's fieldwork. We also thank the reviewers for their insightful and helpful comments.

407

408

409

410

411

412

413

414

415

416

417

418

419

420

421

422

423

424

425

426

427

428

429

\section{References}

Adey WH. 1998. Review-coral reefs: structured and mediated ecosystems in shallow, turbulent, alkaline waters. Journal of Phycology 34:393-406. DOI: 10.1046/j.15298817.1998.340393.x.

Adey WH, Vassar JM. 1975. Colonization, succession and growth rates of tropical crustose coralline algae (Rhodophyta, Cryptonemiales). Phycologia 14:55-69. DOI: 10.2216/i0031-8884-14-2-55.1.

Airoldi L. 2000. Effects of disturbance, life histories, and overgrowth on coexistence of algal crusts and turfs. Ecology 81:798-814. DOI: 10.1890/00129658(2000)081[0798:EODLHA]2.0.CO;2.

Alvarado JJ. 2012. Estado e impacto de Diadema mexicanum A. Agassiz, 1863 (Echinoidea) en los arrecifes coralinos del Pacífico Tropical Oriental. Doctorate in Marine and Coastal sciences Thesis. Baja California Sur: Autonomous University of Baja California Sur.

Alvarado JJ, Reyes-Bonilla H, Buitrago F, Aguirre-Rubí J, Álvarez del Castillo Cardenas PA. 2010. Coral reefs of the Pacific coast of Nicaragua. Coral Reefs 29:201-201. DOI: 10.1007/s00338-009-0570-0.

Anderson MJ, Gorley RN, Clarke KR. 2008. PERMANOVA+ for PRIMER: Guide to Software and Statistical Methods. PRIMER-E: Plymouth, UK.

Arrivillaga A, Escamilla M, Sagastizado M, Muñoz V, Walter M, López WA, Pineda L, Rivas J. 2010. Propuesta de Plan de Manejo del àrea Natural Protegida Complejo Los Cóbanos. El Salvador: USAID Improved Management and Conservation of Critical Watersheds. 
430 Benfield S, Baxter L, Guzman HM, Mair JM. 2008. A comparison of coral reef and coral

431

432

433

434

435

436

437

438

439

440

441

442

443

444

445

446

447

448

449

450

451

452

community fish assemblages in Pacific Panama and environmental factors governing their structure. Journal of the Marine Biological Association of the United Kingdom 88:1331-1341. DOI: 10.1017/S0025315408002002.

Bennett EB. 1966. Monthly charts of surface salinity in the Eastern Tropical Pacific Ocean. Inter-American Tropical Tuna Commission Bulletin 11:1-44.

Burkepile D, Hay M. 2009. Nutrient versus herbivore control of macroalgal community development and coral growth on a Caribbean reef. Marine Ecology Progress Series 389:71-84. DOI: $10.3354 / \operatorname{meps} 08142$.

Carpenter RC, Hackney JM, Adey WH. 1991. Measurements of primary productivity and nitrogenase activity of coral reef algae in a chamber incorporating oscillatory flow. Limnology and Oceanography 36:40-49. DOI: 10.4319/1o.1991.36.1.0040.

Carpenter RC, Williams SL. 2007. Mass transfer limitation of photosynthesis of coral reef algal turfs. Marine Biology 151:435-450. DOI: 10.1007/s00227-006-0465-3.

Cole RG, Syms C, Davey NK, Gust N, Notman P, Stewart R, Radford CA, Carbines G, Carr MH, Jeffs AG. 2007. Does breathing apparatus affect fish counts and observations? A comparison at three New Zealand fished and protected areas. Marine Biology 150:13791395. DOI: $10.1007 / \mathrm{s} 00227-006-0420-3$.

Cortés J. 1997. Biology and geology of eastern Pacific coral reefs. Coral Reefs 16:S39-S46. DOI: $10.1007 / \mathrm{s} 003380050240$.

Cortés J, Enochs IC, Sibaja-Cordero J, Hernández L, Alvarado JJ, Breedy O, Cruz-Barraza JA, Esquivel-Garrote O, Fernández-García C, Hermosillo A, Kaiser KL, Medina-Rosas P, Morales-Ramírez Á, Pacheco C, Pérez-Matus A, Reyes-Bonilla H, Riosmena-Rodríguez 
453

454

455

456

457

458

459

460

461

462

463

464

465

466

467

468

469

470

471

472 Fischer W, Krupp F, Schneider C, Sommer C, Carpenter KE, Niem V. Guia FAO para

473

474

475

R, Sánchez-Noguera C, Wieters EA, Zapata FA. 2017. Marine Biodiversity of Eastern Tropical Pacific Coral Reefs. In: Glynn PW, Manzello DP, Enochs IC eds. Coral Reefs of the Eastern Tropical Pacific. Springer Netherlands, 203-250. DOI: 10.1007/978-94-0177499-4_7.

De O. Figueiredo MA, Kain ( Jones) JM, Norton TA. 2000. Responses of crustose corallines to epiphyte and canopy cover. Journal of Phycology 36:17-24. DOI: 10.1046/j.15298817.2000.98208.x.

Dethier MN. 1994. The ecology of intertidal algal crusts: variation within a functional group. Journal of Experimental Marine Biology and Ecology 177:37-71. DOI: 10.1016/00220981(94)90143-0.

Dickens LC, Goatley CHR, Tanner JK, Bellwood DR. 2011. Quantifying Relative Diver Effects in Underwater Visual Censuses. PLoS ONE 6:e18965. DOI: 10.1371/journal.pone.0018965.

Dominici-Arosemena A, Wolff M. 2006. Reef fish community structure in the Tropical Eastern Pacific (Panamá): living on a relatively stable rocky reef environment. Helgoland Marine Research 60:287-305. DOI: 10.1007/s10152-006-0045-4.

English SA, Wilkinson C, Baker V, Australian Institute of Marine Science (eds.). 1997. Survey manual for tropical marine resources. Townsville: Australian Institute of Marine Science.

identification de especies para lo fines de la pesca. Pacifico Centro-Oriental. Rome: FAO.

Foster SA. 1987. The relative impacts of grazing by Caribbean coral reef fishes and Diadema: 
effects of habitat and surge. J. Exp. Mar. Biol. Ecol. 105:1-20.

477 Francini-Filho RB, Ferreira CM, Coni EOC, De Moura RL, Kaufman L. 2010. Foraging activity 478 of roving herbivorous reef fish (Acanthuridae and Scaridae) in eastern Brazil: influence of resource availability and interference competition. Journal of the Marine Biological

481 482 Association of the United Kingdom 90:481-492. DOI: 10.1017/S0025315409991147.

Glynn PW, Ault JS. 2000. A biogeographic analysis and review of the far eastern Pacific coral reef region. 19 1:1-23. DOI: https://doi.org/10.1007/s003380050220.

González-Cuéllar OT, Reyes-Bonilla H, Fourriére M, Rojo M, Hernández-Velasco A, SánchezAlcántara I, Pfister T. 2013. Range extensions of four species of parrotfishes (Scaridae) in the northern Gulf of California, Mexico. Cybium 37:223-226.

Green AL, Bellwood DR, International Union for Conservation of Nature. 2009. Monitoring functional groups of herbivorous reeffishes as indicators of coral reef resilience: a practical guide for coral reef managers in the Asia Pacific region.

Guzmán HM, Cortés J. 1993. Arrecifes coralinos del Pacífico Oriental Tropical: Revisión y Perspectivas. Rev.Biol.Trop. 41.

Harvey E, Fletcher D, Shortis MR, Kendrick GA. 2004. A comparison of underwater visual distance estimates made by scuba divers and a stereo-video system: implications for underwater visual census of reef fish abundance. Marine and Freshwater Research 55:573. DOI: 10.1071/MF03130.

Herrera A. 2017. Plan de desarrollo local sostenible: Área de conservación Los Cóbanos. El Salvador: Fondo de la Iniciativa para las Américas El Salvador (FIAES).

Heyward AJ, Negri AP. 1999. Natural inducers for coral larval metamorphosis. Coral Reefs 18:273-279. DOI: 10.1007/s003380050193. 
499 Hixon MA. 2015. Predation: piscivory and the ecology of coral reef fishes. In: Mora C ed. 500 Ecology of Fishes on Coral Reefs. Cambridge: Cambridge University Press, 41-52. DOI:

501 10.1017/CBO9781316105412.007.

502 Hoegh-Guldberg O, Kennedy EV, Beyer HL, McClennen C, Possingham HP. 2018. Securing a 503 Long-term Future for Coral Reefs. Trends in Ecology \& Evolution 33:936-944. DOI:

505

506

507

508

509

510

\section{1}

512

513

514

515

516

517

518

519

520

521 10.1016/j.tree.2018.09.006.

Hughes TP, Rodrigues MJ, Bellwood DR, Ceccarelli D, Hoegh-Guldberg O, McCook L, Moltschaniwskyj N, Pratchett MS, Steneck RS, Willis B. 2007. Phase Shifts, Herbivory, and the Resilience of Coral Reefs to Climate Change. Current Biology 17:360-365. DOI: 10.1016/j.cub.2006.12.049.

Jackson J, Donovan M, Kramer K, Lam V. 2014. Status and Trends of Caribbean Coral Reefs: 1970-2012. Global Coral Reef Monitoring Network, IUCN.

Jokiel PL, Rodgers KS, Brown EK, Kenyon JC, Aeby G, Smith WR, Farrell F. 2015. Comparison of methods used to estimate coral cover in the Hawaiian Islands. PeerJ 3:e954. DOI: $10.7717 /$ peerj.954.

Kendrick GA. 1991. Recruitment of coralline crusts and filamentous turf algae in the Galapagos archipelago: effect of simulated scour, erosion and accretion. Journal of Experimental Marine Biology and Ecology 147:47-63. DOI: 10.1016/0022-0981(91)90036-V.

Kessler WS. 2006. The circulation of the eastern tropical Pacific: A review. Progress in Oceanography 69:181-217. DOI: 10.1016/j.pocean.2006.03.009.

King AJ, George A, Buckle DJ, Novak PA, Fulton CJ. 2018. Efficacy of remote underwater video cameras for monitoring tropical wetland fishes. Hydrobiologia 807:145-164. DOI: 10.1007/s10750-017-3390-1. 
522 Langlois T, Harvey E, Fitzpatrick B, Meeuwig J, Shedrawi G, Watson D. 2010. Cost-efficient 523 sampling of fish assemblages: comparison of baited video stations and diver video

524 transects. Aquatic Biology 9:155-168. DOI: 10.3354/ab00235.

525 Lawrence MA. 2016. Easy Analysis and Visualization of Factorial Experiments.

526 Lewis SM. 1986. The Role of Herbivorous Fishes in the Organization of a Caribbean Reef

527 Community. Ecological Monographs 56:183-200. DOI: 10.2307/2937073.

528 Littler MM, Littler DS. 1980. The Evolution of Thallus Form and Survival Strategies in Benthic 529 Marine Macroalgae: Field and Laboratory Tests of a Functional Form Model. The $530 \quad$ American Naturalist 116:25-44.

531 Menge BA, Lubchenco J, Ashkenas LR. 1986. Experimental separation of effects of consumers 532 on sessile prey in the low zone of a rocky shore in the bay of Panama: direct and indirect 533 consequences of food web complexity. Exp. Mar. Biol. Ecol. 100:225-269.

534 Mills SC, Peyrot-Clausade M, France Fontaine M. 2000. Ingestion and transformation of algal 535 turf by Echinometra mathaei on Tiahura fringing reef (French Polynesia). Journal of

536 Experimental Marine Biology and Ecology 254:71-84. DOI: 10.1016/S0022-

537 0981(00)00264-1.

538

Molina OA. 1996. Comparación de la cobertura de los arrecifes coralinos antes y después del derrame de petróleo, Los Cóbanos, Sonsonate 1993 - 1995. Escuela de Biología, Univ. El Salvador, San Salvador.

541 Mumby PJ. 2009. Herbivory versus corallivory: are parrotfish good or bad for Caribbean coral 542 reefs? Coral Reefs 28:683-690. DOI: 10.1007/s00338-009-0501-0.

543 Nelson BV, Vance RR. 1979. Diel foraging patterns of the sea urchin Centrostephanus coronatus 544 as a predator avoidance strategy. Marine Biology 51:251-258. DOI: 
546 Pandolfi JM, Jackson JBC, Baron N, Bradbury RH, Guzmán HM, Hughes TP, Kappel CV, 547 Micheli F, Ogden JC, Possingham HP, Sala E. 2005. Are U.S. Coral Reefs on the 548 Slippery Slope to Slime? Science 307:1725-1726. DOI: 10.1126/science.1104258.

549 Prugh LR, Stoner CJ, Epps CW, Bean WT, Ripple WJ, Laliberte AS, Brashares JS. 2009. The 550 Rise of the Mesopredator. BioScience 59:779-791. DOI: 10.1525/bio.2009.59.9.9.

551 Purcell SW, Bellwood DR. 1993. A functional analysis of food procurement in two surgeonfkh

552

553

554

555

556

557

558

559

560

561

562

563

564

565

566

567

568 species, Acanthurus nigtofuscus and Ctenochaetus striatus (Acantlmridae). Environmental Biology of Fishes:139-159.

Reyes-Bonilla H, Barraza JE. 2003. Corals and associated marine communities from El Salvador. In: Latin American Coral Reefs. Elsevier, 351-360. DOI: 10.1016/B978044451388-5/50016-3.

QGIS.org. 2019. QGIS Geographic Information System. Open Source Geospatial Foundation Project. http://qgis.org

Ritson-Williams R, Paul VJ, Arnold SN, Steneck RS. 2010. Larval settlement preferences and post-settlement survival of the threatened Caribbean corals Acropora palmata and A. cervicornis. Coral Reefs 29:71-81. DOI: 10.1007/s00338-009-0555-z.

Robertson DR, Allen GR. 2015.Shorefishes of the Tropical Eastern Pacific: online information system: Version 2.0 Smithsonian. Available at http://biogeodb.stri.si.edu/sftep/en/pages (accessed September 18, 2018).

Roff G, Mumby PJ. 2012. Global disparity in the resilience of coral reefs. Trends in Ecology \& Evolution 27:404-413. DOI: 10.1016/j.tree.2012.04.007.

Roth F, Stuhldreier I, Sánchez-Noguera C, Morales-Ramírez A, Wild C. 2015. Effects of simulated overfishing on the succession of benthic algae and invertebrates in an 
569

570

571 Segal B, Castro CB. 2001. A proposed method for coral cover assessment: A case study in upwelling-influenced coral reef of Pacific Costa Rica. Journal of Experimental Marine Biology and Ecology 468:55-66. DOI: 10.1016/j.jembe.2015.03.018.

572 Abrolhos, Brazil. Bulletin of Marine Science 69:10.

573

574

Segovia JV. 2016. Impacto de El Niño 2015 en la mortalidad de corales del ANP Los Cóbanos,

575

576

577

578

579

580

581

582

583

584

585

586

587

588

589

590

591 El Salvador.

Segovia JV. 2020. Dinámica bentónica del arrecife de Los Cóbanos. San Salvador, El Salvador: Instituto de Ciencia, Tecnología e Innovación, Universidad Francisco Gavidia.

Segovia J, Navarrete Calero MT. 2007. Biodiversidad a nivel de ecosistema en parches de corales hermatípicos en la zona intermareal de la playa Los Cóbanos, Departamento de Sonsonate, El Salvador (Tesis).

Segovia J, Trejo A, Ramos F. 2019. Informe final. Estado actual de la salud del arrecife de Los Cóbanos con la sugerencia de indicadores para un monitoreo comunitario. Consultoría para el Proyecto Regional de Biodiversidad Costera. Unión Internacional para la Conservación de la Naturaleza. Oficina Regional para México, América Central y el Caribe.

Smith JE, Hunter CL, Smith CM. 2010. The effects of top-down versus bottom-up control on benthic coral reef community structure. Oecologia 163:497-507. DOI: 10.1007/s00442009-1546-z.

Smith J, Smith C, Hunter C. 2001. An experimental analysis of the effects of herbivory and nutrient enrichment on benthic community dynamics on a Hawaiian reef. Coral Reefs 19:332-342. DOI: 10.1007/s003380000124.

Steneck RS. 1995. Is herbivore loss more damaging to reefs than hurricanes? Case studies from 
593 Stewart-Oaten A, Murdoch WW, Parker KR. 1986. Environmental Impact Assessment:

594 "Pseudoreplication" in Time? Ecology 67:929-940. DOI: 10.2307/1939815.

595 Stuhldreier I, Sánchez-Noguera C, Rixen T, Cortés J, Morales A, Wild C. 2015. Effects of

596

597

Seasonal Upwelling on Inorganic and Organic Matter Dynamics in the Water Column of

598 Eastern Pacific Coral Reefs. PLOS ONE 10:e0142681. DOI:

598 10.1371/journal.pone.0142681.

Tâmega FTS, Figueiredo MAO. 2019. Colonization, Growth and Productivity of Crustose Coralline Algae in Sunlit Reefs in the Atlantic Southernmost Coral Reef. Frontiers in

601 Marine Science 6. DOI: 10.3389/fmars.2019.00081.

602

Tebbett SB, Goatley CHR, Bellwood DR. 2017. The Effects of Algal Turf Sediments and 603 Organic Loads on Feeding by Coral Reef Surgeonfishes. PLOS ONE 12:e0169479. DOI:

604 10.1371/journal.pone.0169479.

605

606

607

Thacker R, Ginsburg D, Paul V. 2001. Effects of herbivore exclusion and nutrient enrichment on coral reef macroalgae and cyanobacteria. Coral Reefs 19:318-329. DOI:

608 $10.1007 / \mathrm{s} 003380000122$.

609

610

Van den Hoek C, Breeman AM, Bak RPM, Van Buurt G. 1978. The distribution of algae, corals and gorgonians in relation to depth, light attenuation, water movement and grazing pressure in the fringing coral reef of Curaçao, Netherlands Antilles. Aquatic Botany 5:1-

Vásquez-Elizondo RM, Enríquez S. 2017. Light Absorption in Coralline Algae (Rhodophyta): A Morphological and Functional Approach to Understanding Species Distribution in a Coral Reef Lagoon. Frontiers in Marine Science 4. DOI: 10.3389/fmars.2017.00297. 
615 Vermeij M, Dailer M, Smith C. 2011. Crustose coralline algae can suppress macroalgal growth 616 and recruitment on Hawaiian coral reefs. Marine Ecology Progress Series 422:1-7. DOI: $617 \quad 10.3354 / \operatorname{meps} 08964$.

618 Villas Bôas AB, Figueiredo MA de O, Villaça RC. 2005. Colonization and growth of crustose 619 coralline algae (Corallinales, Rhodophyta) on the Rocas Atoll. Brazilian Journal of 620 Oceanography 53:147-156. DOI: 10.1590/S1679-87592005000200005.

621 Vinueza LR, Branch GM, Branch ML, Bustamante RH. 2006. Top-down herbivory and bottom622 up El Niño effects on Galápagos rocky-shore communities. Ecological Monographs $623 \quad 76: 22$.

624 Vinueza LR, Menge BA, Ruiz D, Palacios DM. 2014. Oceanographic and climatic variation 625 drive top-down/bottom-up coupling in the Galápagos intertidal meta-ecosystem. 626 Ecological Monographs 84:411-434.

627 Weiss A, Martindale RC. 2017. Crustose coralline algae increased framework and diversity on 628 ancient coral reefs. PLOS ONE 12:e0181637. DOI: 10.1371/journal.pone.0181637.

629 Wickham H, Chang W, Henry L, Pedersen TL, Takahashi K, Wilke C, Woo K, Yutani H, 630 Dunnington D. 2019. Package 'ggplot2': Create Elegant Data Visualisations Using the 631 Grammar of Graphics.

632 Willis TJ, Babcock RC. 2000. A baited underwater video system for the determination of relative 633 634 density of carnivorous reef fish. Marine Freshwater Research:755-763. DOI:

635 10.1071/MF00010 1323-1650/00/080755.

Wraith J, Lynch T, Minchinton T, Broad A, Davis A. 2013. Bait type affects fish assemblages 636 and feeding guilds observed at baited remote underwater video stations. Marine Ecology Progress Series 477:189-199. DOI: 10.3354/meps10137. 
638 Zaneveld JR, Burkepile DE, Shantz AA, Pritchard CE, McMinds R, Payet JP, Welsh R, Correa

639 AMS, Lemoine NP, Rosales S, Fuchs C, Maynard JA, Thurber RV. 2016. Overfishing

640 and nutrient pollution interact with temperature to disrupt coral reefs down to microbial

641 scales. Nature Communications 7. DOI: 10.1038/ncomms11833.

642

643 


\section{Table 1 (on next page)}

Relative cover of the benthic community surveyed at Los Cóbanos reef using the Line Point Intercept method 
1

\begin{tabular}{llc}
\hline & Genus/Group & Mean cover \pm SD \\
\hline Chlorophyta & Codium sp. & $7.9 \pm 12.7$ \\
Phaeophyta & Halimeda sp. & $14.9 \pm 8.5$ \\
& Padina sp. & $5.4 \pm 4.0$ \\
& Ralfsia sp. & $1.6 \pm 1.9$ \\
& Colpomenia sp. & $0.3 \pm 0.5$ \\
Rhodophyta & Dictyota sp. & $8.6 \pm 6.4$ \\
& Galaxaura sp. & $2.7 \pm 2.7$ \\
& Ceramium sp. & $3.5 \pm 2.9$ \\
Turf & Acanthophora sp. & $3.3 \pm 8.6$ \\
Cnidaria & CCA & $10.0 \pm 3.1$ \\
Rock & Rodoliths & $0.7 \pm 0.8$ \\
Sand & - & $26.6 \pm 8.8$ \\
Skeleton & Porites lobata & $2.0 \pm 2.8$ \\
\hline
\end{tabular}

2

3 
Figure 1

Pacific coast of El Salvador

Square indicates Los Cóbanos reef where the monitoring and experimental set-up took place.

Red dots: survey area. Map generated with QGIS2.18.13 ( $\underline{\text { http://qgis.org ) }}$

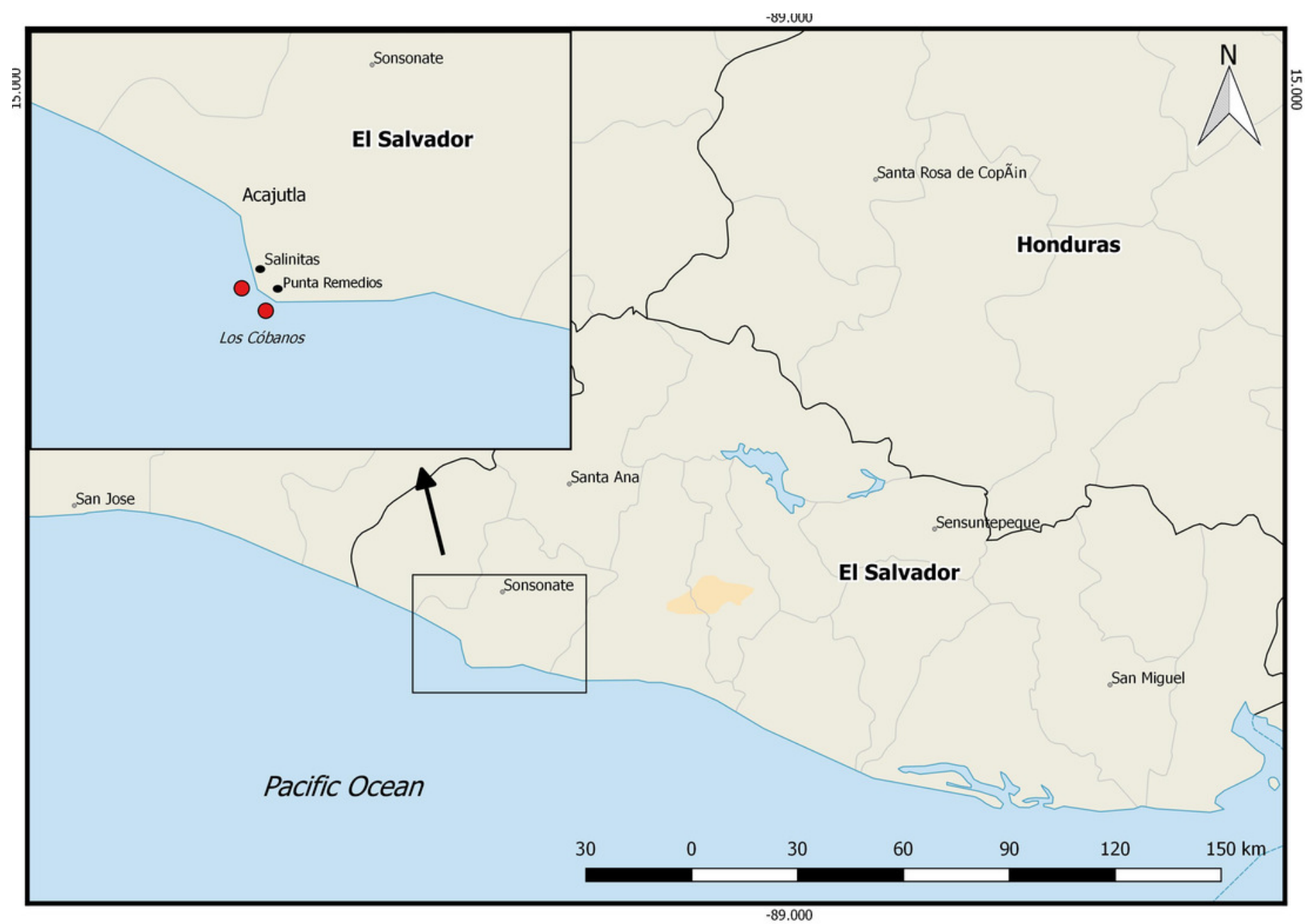


Figure 2

Benthic communities before and after exlosure experiment

Non-metric multidimensional scaling (nMDS) plot of control and enclosed (cage) benthic community composition before and after 7 weeks of experiment using Bray-Curtis similarity.

Dashed circles: $60 \%$ similarity, continuous circles $40 \%$ similarity. Random variation added using the jitter function to reveal points overlapping (ggplot2 package, Wickham et al., 2019).

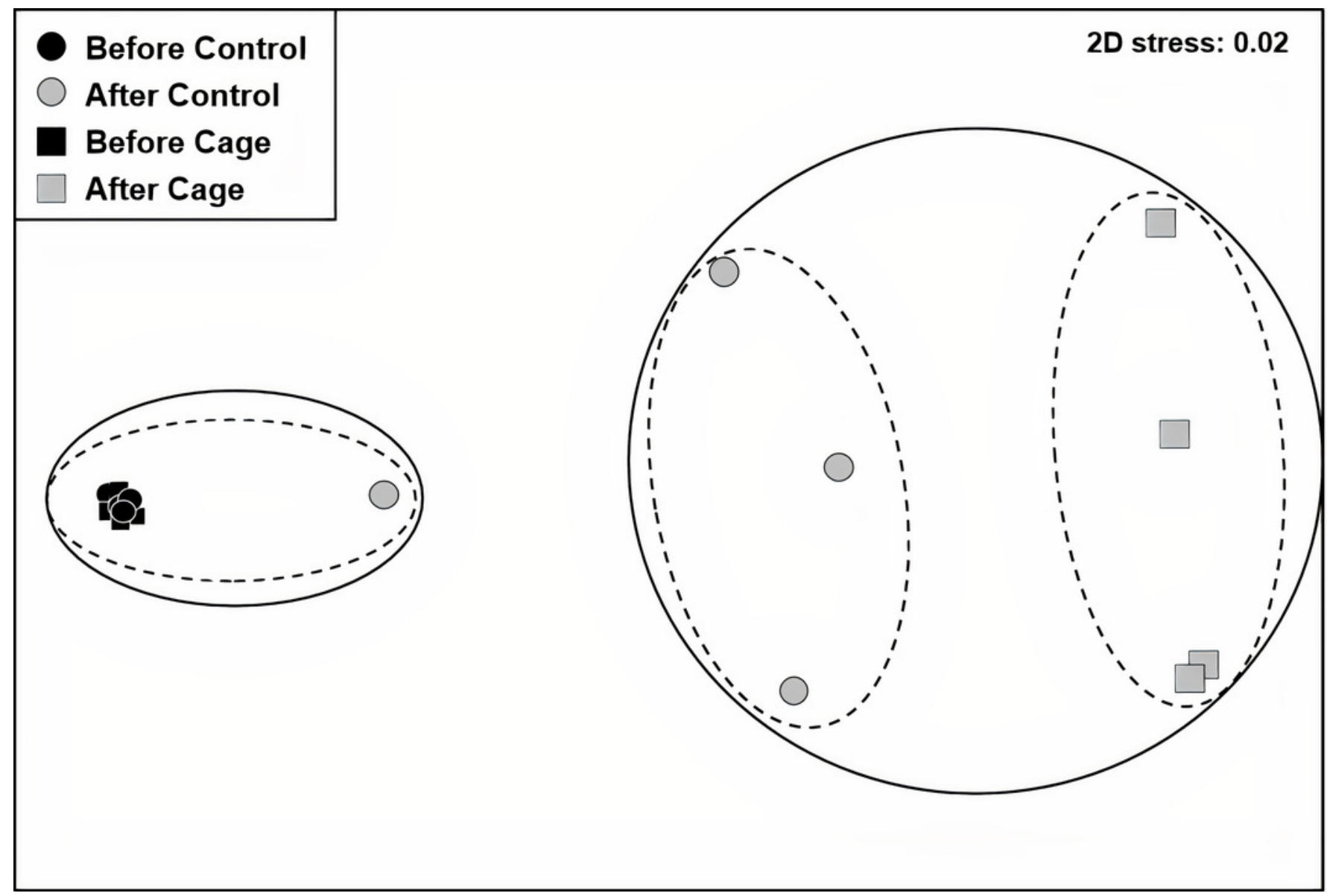




\section{Figure 3}

Crustose coralline and turf algae cover in the enclosed and control plots before and after the experiment

a) CCA cover before and after the experiment b) Turf algae cover before and after the experiment (Supplementary Materials, Table S2)
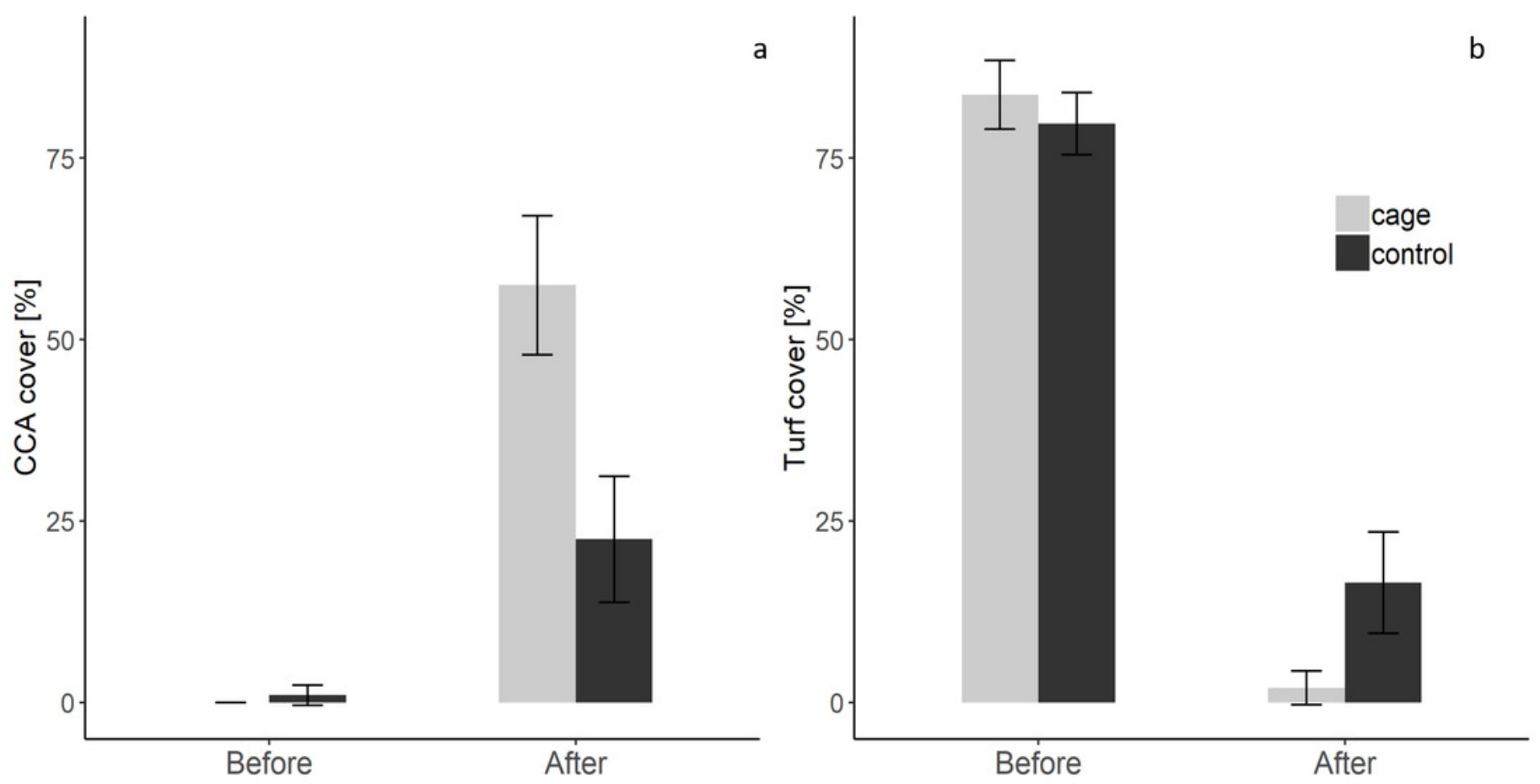